\title{
Pichia amethionina, a New Heterothallic Yeast Associated with the Decaying Stems of Cereoid Cacti
}

\author{
W. T. STARMER, $\dagger$ H. J. PHAFF, MARY MIRANDA, AND M. W. MILLER \\ Department of Food Science and Technology, University of California, Davis, California 95616
}

\begin{abstract}
A new species of the genus Pichia has been recovered 38 times in the Sonoran Desert from "rot pockets" of cereoid cacti and from Drosophila species which utilize the cacti. We have named the species Pichia amethionina due to its absolute requirement for methionine or cysteine. $P$. amethionina is heterothallic and demonstrates an agglutination reaction when opposite mating types are mixed. Two varieties are designated based on the combination of mannitol assimilation and ecological habitat. $P$. amethionina var. amethionina, the type variety, was recovered from cacti in the subtribe Stenocereinae and cannot assimilate mannitol, whereas $P$. amethionina var. pachycereana was found in cacti of the subtribe Pachycereinae and can assimilate mannitol. Results are given which demonstrate that the assimilation of mannitol is controlled by a single genetic locus. An evaluation of the interfertility and postmating viability among the two varieties and possibly identical organisms was made. The base composition of the nuclear deoxyribonucleic acid (average of 10 strains) is 33.05 $\pm 0.19 \mathrm{~mol} \%$ guanine plus cytosine. The type strain of $P$. amethionina and of the type variety, $P$. amethionina var. amethionina, is UCD-FST 76-401B (=ATCC $36080=$ CBS 6940 ). The type strain of $P$. amethionina var. pachycereana is UCD-FST 76-384A (=ATCC $36079=$ CBS 6943).
\end{abstract}

Most yeasts we have recovered from cactus necroses are cactus specific $(6,7)$. The host specificity ranges from species which occur predominantly in one major host plant (e.g., Pichia heedii [8]) to species which inhabit many cactus substrates but which are limited to cacti in general (e.g., P. cactophila [12]). The ultimate causes for specific associations have yet to be determined and probably involve interaction at various levels of biological organization. Nevertheless, the first important step for uncovering causal components is a thorough taxonomic treatment of the yeast florae found in the cactus "soft-rot" habitat. Some of the factors which are necessary for species determination are: (i) physiological profiles as revealed by tests of assimilation, fermentation, and physiological tolerance of various compounds; (ii) sexuality and interfertility among isolates; (iii) characterization of the nuclear deoxyribonucleic acids (DNAs) of representative strains; (iv) ecological constraints and flexibilities exhibited by the natural habitat and physical environment, and (v) genetic cohesiveness indicated by coordinated observations on the physiology, ecology, and sexual fertility of geographically widespread representative strains.

An earlier survey of cactus soft-rots $(3,11)$

$\dagger$ Present address: Department of Biology, Syracuse University, Syracuse, NY 13210. revealed a yeast similar to $P$. delftensis Beech occurring in the necroses of Carnegia gigantea (Engelm.) Britt. and Rose and the associated fly Drosophila nigrospiracula Patterson and Wheeler. The cactus yeast strains were found to have nuclear DNA base compositions almost identical with that of $P$. delftensis and only minor differences in physiological profile. However, the type strain of $P$. delftensis had been isolated from apple juice in England, and it has a lower maximum temperature for growth (4). The dissimilarity of habitats for the cactus yeast and $P$. delftensis was suggestive of different species; yet taken alone, the evidence for different species was not sufficient. Additional surveys of cactus soft-rots and subsequent laboratory studies revealed that the yeast isolates from cactus were unique in several respects. Probably the most striking characteristic is an absolute requirement for methionine or cysteine, the sulfur-containing amino acids.

In addition, single-spore isolates of representative strains showed the species to be heterothallic and to possess a strong agglutination reaction when opposite mating types are mixed. This provided the necessary material for demonstrating fertility or infertility among strains and with possibly identical organisms. Matings between single-spore clones derived from the cactus isolates with $P$. delftensis asporogenous single-spore clones were unsuccessful. 
When the habitat, methionine requirement, and sexual fertility are considered together, the cactus isolates constitute a distinct species different from $P$. delftensis. We have named this new species $P$. amethionina due to the inability of the organism to synthesize methionine from ammonium sulfate. Furthermore, we have recognized two varieties based on ability to assimilate D-mannitol and on ecological associations with two different subtribes of cacti. P. amethionina var. amethionina, the type variety, is found mainly in some cacti belonging to the subtribe Stenocereinae and cannot assimilate D-mannitol. P. amethionina var. pachycereana can assimilate D-mannitol and is found predominantly in soft-rots of some cactus species belonging to the subtribe Pachycereinae.

\section{MATERIALS AND METHODS}

Samples of necrotic cactus tissue were collected in various areas of the North American Sonoran Desert (Fig. 1). Most of the isolations were accomplished by streaking a loopful of necrotic tissue directly on acidified yeast extract-malt extract agar (Difco YM agar $+0.7 \%$ [vol/vol] $1 \mathrm{~N} \mathrm{HCl}=\mathrm{AYM}, \mathrm{pH} 3.7$ to 3.8 ) in the field. In some cases, dilutions of the tissue were made in sterile water as described earlier (11). The plates were stored at ambient temperatures (24 to $30^{\circ} \mathrm{C}$ ) until colonies appeared. Counts of morphologically distinct colony types were then made, and a representative of each type was brought into pure culture by two successive platings on YM agar for identification. Based on the subsequent identification and recognition of $P$. amethionina as a separate species, the colonies of this species on the isolation medium were recognized as convex, highly glossy to

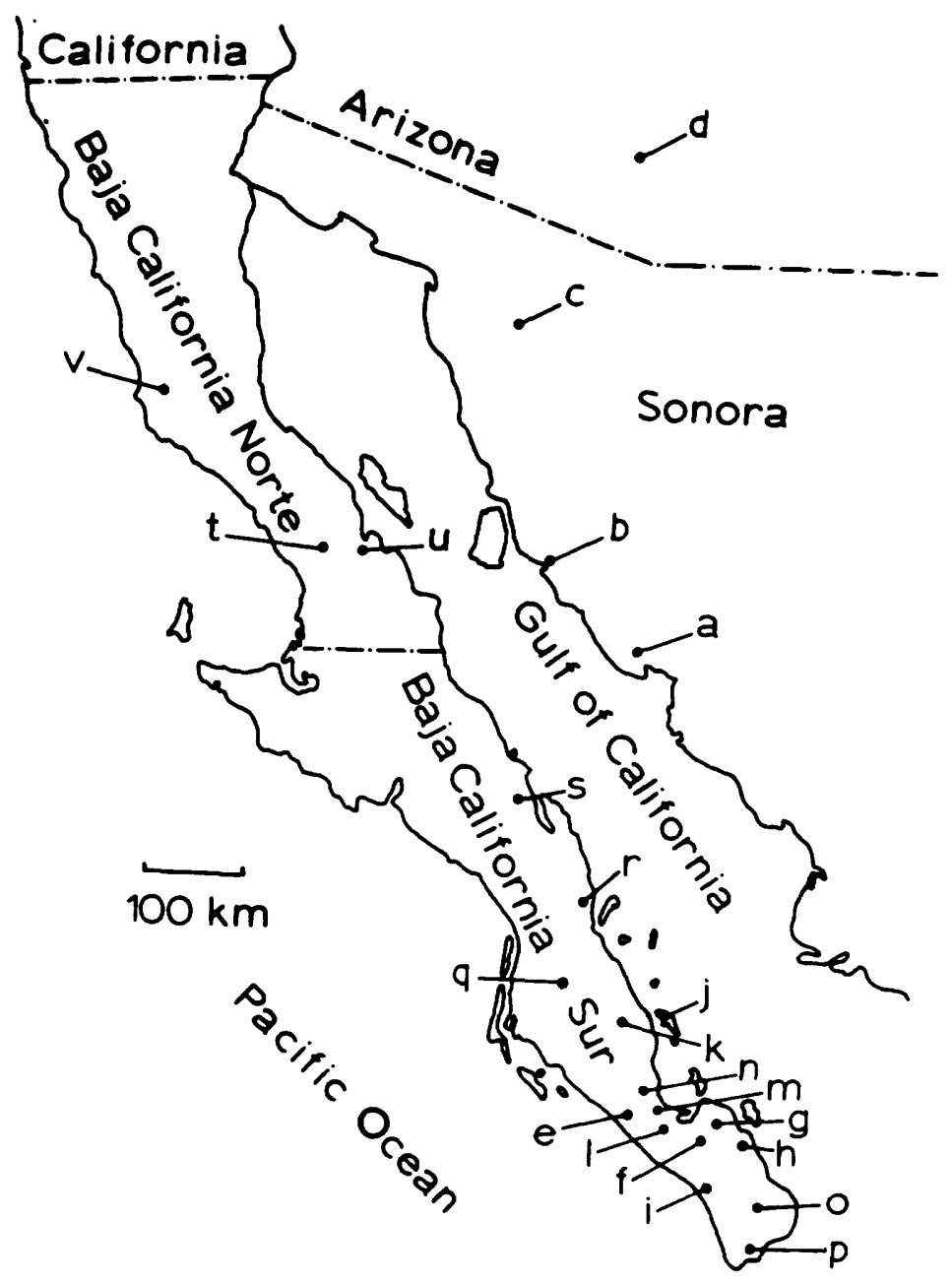

Fig. 1. Collection localities for isolates of Pichia amethionina listed in Table 1. 
glossy, and smooth but sometimes with a textured surface.

Some isolates were obtained from adult drosophilae captured near cacti with necrotic tissue. The flies were surface sterilized in $70 \%$ ethanol (for about $1 \mathrm{~min}$ ), rinsed in $10 \mathrm{ml}$ of sterile water, and then squashed and streaked directly on AYM agar plates in the field.

Identification was done by standard methods currently used in yeast taxonomy (14). DNA extraction and purification were done by a combination of the procedures of Marmur (5) and Bernardi et al. (1). The guanine-plus-cytosine $(\mathrm{G}+\mathrm{C})$ content of the DNA was calculated from buoyant-density values in cesium chloride $(10,13)$ and was based on two to six separate determinations. Micrococcus lysodeikticus DNA, with a buoyant density of $1.7311 \mathrm{~g} / \mathrm{ml}$, was used as a reference. The buoyant density of the $M$. lysodeikticus DNA was derived from comparison with plasmid-free Escherichia coli K-12 DNA, the buoyant density of which was taken to be 1.7100 .

Single ascospores were isolated from mature asci with a micromanipulator (2) and sometimes after treatment of the sporulating suspension of cells and asci with the cell wall-digesting enzyme Zymolyase.

\section{RESULTS}

\section{Latin diagnosis of Pichia amethionina sp. nov.}

Pichia amethionina var. amethionina var. nov. In extracto malti cellulae cylindricae aut ovoideae, 1.6-4.3 $\times$ 4.0-9.3 $\mu \mathrm{m}$, interdum longitudo $12.2 \mu \mathrm{m}$, singulae, binae, in catenis brevis, aut in fasciculae; pellicula nulla aut tenuis, nonnitida.

Cultura in agaro malti post unum mensem $\left(25^{\circ} \mathrm{C}\right)$ crocea (in centro) et cana (in margine), butyrosa vel mollis, umbonata, glabra cum lineis radiatis, patula, nitida vel semi-nitida, margine glabro vel undulato.

In agaro farinae Zea maïs post dies 10 , pseudomycelium nullum; interdum paucae cellulae oblongae formantur. Species heterothallica, diploidea aut haploidea. Asci ex cellulae diploidae inconjugati fiunt, habentes 4 sporos pileiformae; asci rumpunter post 5-7 dies.

Fermentatio glucosi nullum.

Glucosum, ethanolum, glycerolum, glucono$\delta$-lactonum, acidum lacticum, et acidum succinicum assimilantur at non galactosum, L-sorbosum, maltosum, saccharum, cellobiosum, trehalosum, lactosum, melibiosum, raffinosum, melezitosum, inulinum, amylum solubile, D-xylosum, L-arabinosum, D-arabinosum, D-ribosum, L-rhamnosum, methanolum, erythritolum, ribitolum, galactitolum, D-mannitolum, D-glucitolum, $\alpha$-methyl-D-glucosidum, salicinum, 2 - et 5ketogluconatum, D-glucosaminum, acidum citricum nec inositolum.

Kalium nitricum et natrium nitrosum non assimilantur.
Ethyl aminum assimilatur.

Ad crescentiam pyridoxinum et thiaminum necessariae sunt.

Crescere potest in $39^{\circ} \mathrm{C}$, interdum in $42^{\circ} \mathrm{C}$.

$\mathrm{G}+\mathrm{C}$ acidi deoxyribonucleati $=33.0-33.1$ mol\% (6 stirpes, vide tabulum 3).

Habitatio in cacti subtribus Stenocereinae.

Typus: Stirps UCD (FST) 76-401B ex tabidosus sacculis cacti Rathbunia alamosensis isolata est.

In collectione zymotica Centraalbureau voor Schimmelcultures, Delphi Batavorum sub. no 6940 deposita est.

Pichia amethionina var. pachycereana var. nov. Varietas a $P$. amethionina var. amethionina differt: D-mannitolum assimilatur. $\mathrm{G}+\mathrm{C}$ acidi deoxyribonucleati $=32.8-33.6 \mathrm{~mol} \%(4$ stirpes, vide tabulum 3 ). Habitatio in cacti subtribus Pachycereinae.

Typus: Stirps UCD (FST) 76-384A ex tabidus sacculis cacti Pachycereus pringlei isolata est.

In collectione zymotica Centraalbureau voor Schimmelcultures, Delphi Batavorum sub no. 6943 deposita est.

\section{Standard description of Pichia amethion- ina sp. nov.}

Pichia amethionina var. amethionina var. nov. Growth in malt extract: After 3 days at $25^{\circ} \mathrm{C}$ the cells are thin, cylindrical, or ovoidal, 1.6 to 4.3 by 4.0 to $9.3 \mu \mathrm{m}$. Occasionally cells occur which are up to $12.2 \mu \mathrm{m}$ long. The thallus consists of single cells, pairs, branched chains, and starlike clusters (Fig. $2 a, b$, and c). A pellicle is usually not formed, but extremely thin, smooth, and dull surface growth may occur. Little sediment is formed.

Growth on malt extract agar: After 1 month at $25^{\circ} \mathrm{C}$, the streak culture is yellowish (central portion) to grayish (periphery), butyrous to soft, umbonate, smooth with slight radial striations, spreading, and glossy to semiglossy; the border is entire to lobulate.

Dalmau plate culture on cornmeal agar: Most strains form no pseudomycelium either aerobically or anaerobically. In a few strains a very rudimentary pseudomycelium is present consisting of a few elongated cells.

Formation of ascospores: The vegetative cells are heterothallic and they are isolated as diploid as well as haploid cells. Ascospores are formed best on YM agar after 5 to 7 days at about $25^{\circ} \mathrm{C}$. The spores are hat-shaped, and there are usually four per ascus. Two of the spores are of mating type $\mathbf{a}$ and two are of mating type $\alpha$. The asci rupture at maturity, releasing the spores soon after formation.

Other characteristics: Ability to ferment is 

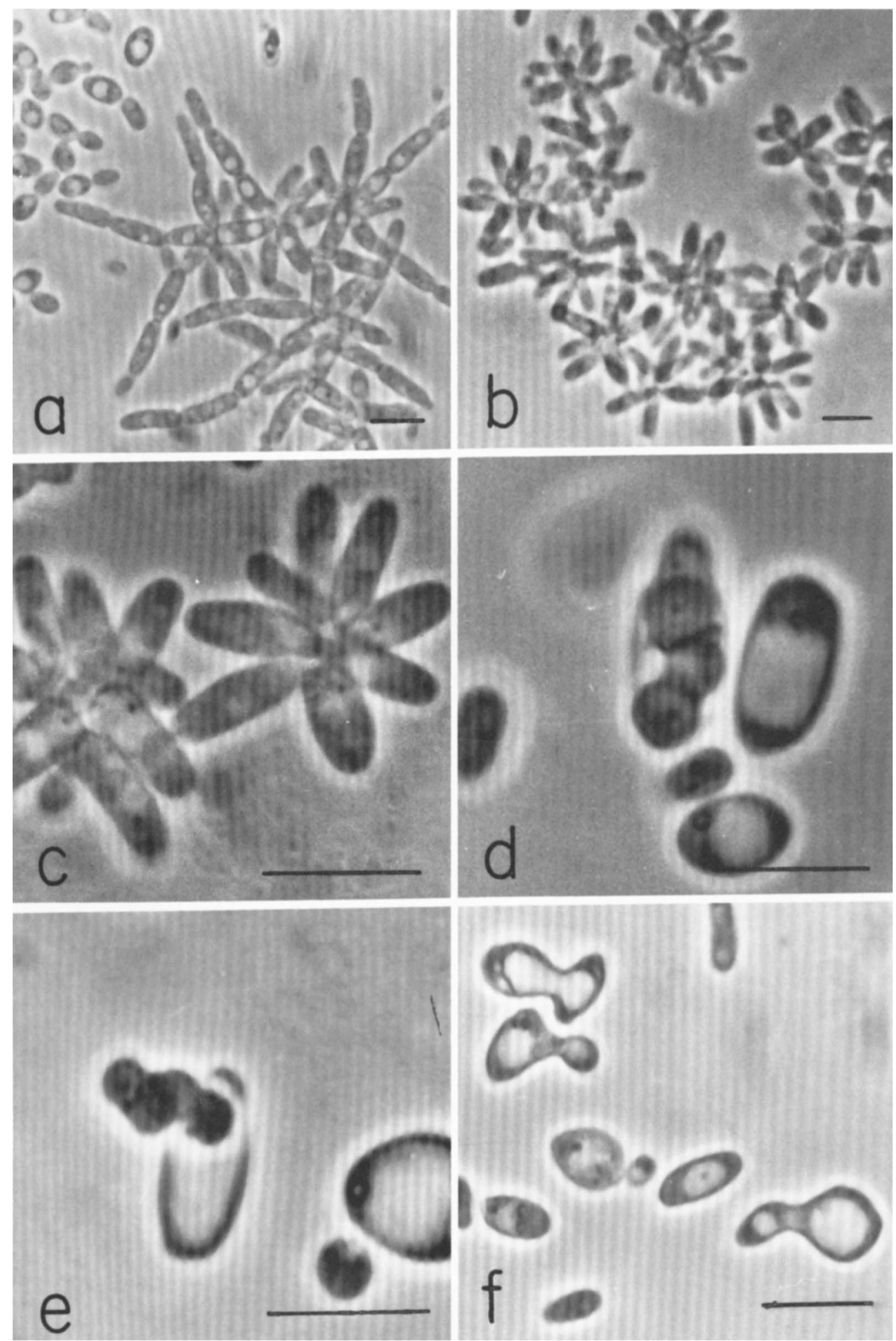
lacking. Assimilation of carbon compounds: Dglucose, ethanol, glycerol, glucono- $\delta$-lactone, Dlactic acid, and succinic acid are assimilated. The following compounds are not assimilated: D-galactose, L-sorbose, maltose, sucrose, cellobiose, trehalose, lactose, melibiose, raffinose, melezitose, inulin, soluble starch, D-xylose, Larabinose, D-arabinose, D-ribose, L-rhamnose, methanol, erythritol, ribitol, galactitol, D-mannitol, D-glucitol, $\alpha$-methyl-D-glucoside, salicin, 2and 5-ketogluconate, D-glucosamine, citric acid, and meso-inositol.

Assimilation of nitrogen compounds: Potassium nitrate, -; sodium nitrite, -; ethylamine, +; ammonium sulfate, + .

Growth in vitamin-free medium: Absent. Pyridoxine and thiamine are required for growth.

Other growth requirements: Sulfate does not serve as a source of sulfur; synthetic media must be supplemented with $10 \mathrm{mg}$ of L-methionine or L-cysteine per liter.

Growth on 50\% (wt/wt) glucose-yeast extract agar: Negative. Growth on $10 \% \mathrm{NaCl}$ plus $5 \%$ glucose in yeast nitrogen base agar: Negative.

Maximum temperature for growth: 39 to $42^{\circ} \mathrm{C}$, depending on the strain.

Acid formation on chalk agar: Negative, occasionally weak.

Hydrolysis of urea: Negative.

Gelatin liquefaction: Negative.

Casein hydrolysis: Negative.

Lipolytic activity: Negative.

Growth in the presence of $0.1 \mathrm{mg}$ of cycloheximide per ml: Negative.

$\mathrm{G}+\mathrm{C}$ content of the nuclear DNA: 33.0 to 33.1 mol\% (six strains, Table 3 ).

Habitat: Twenty-eight strains were recovered in Baja California, and the State of Sonora, Mexico (Tables 1 and 2, Fig. 1) from necrotic tissue of various species of cacti, predominantly members of the subtribe Stenocereinae.

Type: The type strain of $P$. amethionina, and thus also of $P$. amethionina var. amethionina, the type variety, is strain UCD (FST) 76-401B; it was isolated from necrotic tissue of Rathbunia alamosensis near Guaymas (Fig. 1, Table 1). It has been deposited in the collection of the Yeast Division of the Centraalbureau voor Schimmelcultures in Delft, The Netherlands, as CBS 6940, and in the American Type Culture Collection,
Rockville, Md., as ATCC 36080.

Etymology: amethionina. L. prep. $a$ without: M.L. n. methioninum methionine; M.L. adj. amethionina without methionine, i.e., pertaining to the organism's lack of biosynthesis of methionine from sulfate.

\section{Pichia amethionina var. pachycereana var.} nov.

Assimilation of D-mannitol: Positive.

$\mathrm{G}+\mathrm{C}$ content of the nuclear DNA: 32.8 to 33.5 mol\% (four strains, Table 3).

Habitat: Ten strains were recovered in various locations of the North American Sonoran Desert (Tables 1 and 2, Fig. 1) from necrotic tissue of various species of cacti, predominantly members of the subtribe Pachycereinae.

Type: The type strain, UCD (FST) 76-384A, was isolated from Pachycereus pringlei near Mulegé, Baja California (Table 1, Fig. 1). It has been deposited in the collection of the Yeast Division of the Centraalbureau voor Schimmelcultures in Delft, The Netherlands, as CBS 6943 and in the American Type Culture Collection, Rockville, Md., as ATCC 36079.

Etymology: pachycereana. M.L. Pachycereinae subtribe of cactus: L. adj. ana association with; M.L. pachycereana referring to its habitat in cactus species of the subtribe Pachycereinae.

\section{DISCUSSION}

$P$. amethionina has an absolute requirement for methionine or cysteine, sulfur-containing amino acids (Table 4). This is due to the inability of the species to convert hydrogen sulfite to hydrogen sulfide, a complex step in the metabolism of sulfate (9). It is noteworthy that some variability exists for the conversion of cystathionine into the required amino acid. The variability is present in both varieties of $P$. amethionina and is exhibited by latent growth (mutation followed by selective adaptation) when cystathionine is used as the precursor. The methionine requirement was found in all strains of $P$. amethionina and is thus widespread (Fig. 1) throughout the Sonoran Desert. This property may be an adaptive character which has allowed the species to assume its present niche in the cactus soft-rot microcosm. The reasons for this

FIG. 2. Vegetative reproduction (3 days at room temperature in malt extract) and ascosporulation of $P$. amethionina. The vegetative cells occur singly, in pairs, or in branched chains (a) and frequently in asteroid 110 formations (b). The extent of asteroid formation is strain dependent. (c) Illustrates the arrangement of the formations (b). The extent of asteroid formation is strain dependent. (c) Illustrates the arrangement of the asteroid clusters as a tendency of buds to form at polar shoulders and remaining undisjuncted. Tightly packed hat- to helmet-shaped spores are formed in diploid cells (d). As the asci dehisce (e) the spores remain associated. Upon mixing of haploid clones derived from single spores, rapid conjugation occurs (f), reestablishing the diploid condition. The bars represent $5 \mu \mathrm{m}$ in all illustrations. 
TABLE 1. Localities and sources for isolates of Pichia amethionina

\begin{tabular}{|c|c|c|c|c|c|}
\hline Variety & & Serial no. & UCD-FST no. & Locality $^{a}$ & Habitat/substrate \\
\hline \multirow[t]{18}{*}{$\begin{array}{l}\text { P. amethionina } \\
\text { amethionina }\end{array}$} & \multirow[t]{18}{*}{ var. } & 1 (type) & $76-401 B$ & $\begin{array}{l}\text { Guaymas, Sonora, Mex- } \\
\text { ico (a) }\end{array}$ & $\begin{array}{l}\text { Rathbunia alamo- } \\
\text { sensis }\end{array}$ \\
\hline & & 2 & $71-152$ & $\begin{array}{l}\text { Bahia Kino, Sonora, } \\
\text { Mexico (b) }\end{array}$ & $\begin{array}{l}\text { Macherocereus gum- } \\
\text { mosus }\end{array}$ \\
\hline & & 3 & $76-217 \mathrm{C}$ & $\begin{array}{l}\text { Rancho Cuñaño, Baja } \\
\text { California Sur, Mexico } \\
\text { (e) }\end{array}$ & M. gummosus \\
\hline & & 4 & $76-219 \mathrm{C}$ & $\begin{array}{l}\text { Las Planos, Baja Califor- } \\
\text { nia Sur, Mexico (g) }\end{array}$ & M. gummosus \\
\hline & & 5 & $76-223 \mathrm{~A}$ & $\begin{array}{l}\text { Punta Pescadero, Baja } \\
\text { California Sur, Mexico } \\
\text { (h) }\end{array}$ & M. gummosus \\
\hline & & 6,7 & $76-233 \mathrm{~A}, 76-240 \mathrm{~B}$ & $\begin{array}{l}\text { Todos Santos, Baja Cali- } \\
\text { fornia Sur, Mexico (i) }\end{array}$ & M. gummosus \\
\hline & & 8,9 & $76-266 \mathrm{~A}, 76-267 \mathrm{~A}$ & $\begin{array}{l}\text { Mission San Luis Gon- } \\
\text { zaga, Baja California } \\
\text { Sur, Mexico (k) }\end{array}$ & M. gummosus \\
\hline & & 10 & $76-279 \mathrm{~A}$ & $\begin{array}{l}\text { La Paz, Baja California } \\
\text { Sur, Mexico (l) }\end{array}$ & M. gummosus \\
\hline & & 11 & $76-284 \mathrm{~A}$ & $\begin{array}{l}\text { El Centenario, Baja Cal- } \\
\text { ifornia Sur, Mexico (m) }\end{array}$ & M. gummosus \\
\hline & & 12 & $76-296 \mathrm{~A}$ & $\begin{array}{l}\text { North of La Paz, Baja } \\
\text { California Sur, Mexico } \\
\text { (n) }\end{array}$ & $\begin{array}{l}\text { Lemaireocereus thur- } \\
\text { beri }\end{array}$ \\
\hline & & $13,14,15$ & $\begin{array}{l}76-297 \mathrm{~B}, 76-299 \mathrm{~A} \\
76-300 \mathrm{~A}\end{array}$ & $\begin{array}{l}\text { Santiago, Baja California } \\
\text { Sur, Mexico (o) }\end{array}$ & M. gummosus \\
\hline & & 16 & $76-309 \mathrm{C}$ & $\begin{array}{l}\text { Palmilla, Baja California } \\
\text { Sur, Mexico (p) }\end{array}$ & M. gummosus \\
\hline & & 17 & $76-315 B$ & $\begin{array}{l}\text { East of Insurgentes, Baja } \\
\text { California Sur, Mexico } \\
\text { (q) }\end{array}$ & M. gummosus \\
\hline & & 18 & $76-320 \mathrm{~A}$ & $\begin{array}{l}\text { Loreto, Baja California } \\
\text { Sur, Mexico (r) }\end{array}$ & M. gummosus \\
\hline & & 19 & $76-344$ & $\begin{array}{l}\text { San Borja, Baja Califor- } \\
\text { nia Norte, Mexico (t) }\end{array}$ & Lophocereus schottii \\
\hline & & 20 & $76-353 \mathrm{~B}$ & $\begin{array}{l}\text { Las Flores, Bahia de Los } \\
\text { Angeles, Baja Califor- } \\
\text { nia Norte, Mexico (u) }\end{array}$ & M. gummosus \\
\hline & & 21 & $76-354 \mathrm{~A}$ & $\begin{array}{l}\text { Mulegé, Baja California } \\
\text { Sur, Mexico (s) }\end{array}$ & M. gummosus \\
\hline & & $\begin{array}{l}22,23,24, \\
25,26,27,28\end{array}$ & $\begin{array}{l}77-352 \mathrm{~A}, 77-354 \mathrm{~B}, \\
77-360 \mathrm{E}, 77-367 \mathrm{~A}, \\
77-390 \mathrm{~A}, 77-399 \mathrm{~A}, \\
77-401 \mathrm{~B}\end{array}$ & $\begin{array}{l}\text { El Socorro, Baja Califor- } \\
\text { nia Norte, Mexico (r) }\end{array}$ & $\begin{array}{l}\text { Drosophila mojaven- } \\
\quad \text { sis }\end{array}$ \\
\hline \multirow[t]{6}{*}{$\begin{array}{l}\text { P. amethionina } \\
\text { pachycereana }\end{array}$} & \multirow[t]{6}{*}{ var. } & 29 & $72-109$ & $\begin{array}{l}\text { Caborca, Sonora, Mexico } \\
\text { (c) }\end{array}$ & L. schottii \\
\hline & & $\begin{array}{l}30,31,32 \\
33,34\end{array}$ & $\begin{array}{l}72-318,72-319 \\
72-321,72-322 \\
73-63\end{array}$ & Tucson, Ariz. (d) & Carnegia gigantea \\
\hline & & 35 & $76-216$ & $\begin{array}{l}\text { Rancho Cuñaño, Baja } \\
\text { California Sur, Mexico } \\
\text { (e) }\end{array}$ & L. schottii \\
\hline & & 36 & $76-227 \mathrm{~A}$ & $\begin{array}{l}\text { San Pedro, Baja Califor- } \\
\text { nia Sur, Mexico (f) }\end{array}$ & Pachycereus pringlei \\
\hline & & 37 & $76-247 \mathrm{~B}$ & $\begin{array}{l}\text { Isla San Jose, Baja Cali- } \\
\text { fornia Sur, Mexico (j) }\end{array}$ & M. gummosus \\
\hline & & 38 (type) & $76-384 \mathrm{~A}$ & $\begin{array}{l}\text { Mulegé, Baja California } \\
\text { Sur, Mexico (s) }\end{array}$ & $P$. pringlei \\
\hline
\end{tabular}

\footnotetext{
${ }^{a}$ The letters in parentheses correspond to the geographic locations shown in Fig. 1.
} 
TABLE 2. Sources and frequencies of isolation of strains of the two varieties of Pichia amethionina

\begin{tabular}{|c|c|c|}
\hline \multirow[b]{2}{*}{ Source } & \multicolumn{2}{|c|}{ No. of strains of: } \\
\hline & $\begin{array}{l}\text { P. amethion- } \\
\text { ina var. ame- } \\
\text { thionina }\end{array}$ & $\begin{array}{l}\text { P. amethion- } \\
\text { ina var. pa- } \\
\text { chycereana }\end{array}$ \\
\hline $\begin{array}{l}\text { Macherocereus gummosus } \\
\text { (Engelm.) Britt. \& } \\
\text { Rose [agria] }^{a}\end{array}$ & 18 & 1 \\
\hline $\begin{array}{c}\text { Drosophila mojavensis } \\
\text { Patterson \& Crow }\end{array}$ & 7 & 0 \\
\hline $\begin{array}{c}\text { Lemaireocereus thurberi } \\
\text { (Engelm.) Britt. \& } \\
\text { Rose [organpipe] }\end{array}$ & 1 & 0 \\
\hline $\begin{array}{l}\text { Rathbunia alamosensis } \\
\text { (Coulter) Britt. \& } \\
\text { Rose [cina] }\end{array}$ & 1 & 0 \\
\hline $\begin{array}{l}\text { Carnegia gigantea } \\
\text { (Engelm.) Britt. \& } \\
\text { Rose [saguaro] }\end{array}$ & 0 & 5 \\
\hline $\begin{array}{l}\text { Lophocereus schottii (En- } \\
\text { gelm.) Britt. \& Rose } \\
\text { [senita] }\end{array}$ & 1 & 2 \\
\hline $\begin{array}{l}\text { Pachycereus pringlei (S. } \\
\text { Wats.) Britt. \& Rose } \\
\text { [cardon] }\end{array}$ & 0 & 2 \\
\hline Total & 28 & 10 \\
\hline
\end{tabular}

${ }^{a}$ Common names of the cacti are in brackets following the scientific names. are unclear, but additional studies into this unique character should provide insight.

Both diploid and haploid strains of $P$. amethionina were recovered from the natural habitats. Haploid strains of both varieties were shown to be interfertile among one another. However, varying degrees of postmating breakdown were indicated by low viability of ascospores. For example, a number of four-spored asci were dissected from a hybrid of the two varieties. The parents (strain $27 \alpha \times$ strain 35 a) of the hybrid were isolated over $800 \mathrm{~km}$ apart on the peninsula of Baja California, Mexico. Fifty dissected asci, containing four spores each, yielded 103 viable spores (viability $=103 / 200=$ $51.5 \%$ ). Parental strains showed about $80 \%$ spore viability. All spore viability classes were present (Table 5), which demonstrates that the inviability is not due to a simple genetic phenomenon such as a reciprocal translocation, where only the zero, two, and four spore viability classes are expected. In fact, the distribution of viability classes fits a binomial distribution $\left(\chi^{2}=9.98\right.$; $\mathrm{df}$ $=4 ; \alpha=0.05$ ), indicating the possibility of multiple genetic factors. One cross between the two varieties (strain $2 \alpha \times$ strain 38 a) produced fourspored asci but $0 \%$ viability $(0 / 40$ spores viable). Other intervarietal crosses demonstrated higher

TABLE 3. Nuclear DNA base compositions of representative strains of $P$. amethionina ${ }^{a}$

\begin{tabular}{|c|c|c|c|c|}
\hline Strain & Locality & Substrate & $\mathrm{Mol} \% \mathrm{G}+\mathrm{C} \pm \mathrm{SD}^{b}$ & $\begin{array}{l}\text { Assimila- } \\
\text { tion of } \\
\text { mannitol }\end{array}$ \\
\hline 1 & Guaymas, Sonora, Mexico & $\begin{array}{l}\text { Rathbunia alamo- } \\
\text { sensis }\end{array}$ & $33.1 \pm 0.14$ & - \\
\hline 2 & Bahia Kino, Sonora, Mexico & $\begin{array}{l}\text { Macherocereus } \\
\text { gummosus }\end{array}$ & $33.0 \pm 0.33$ & - \\
\hline 17 & $\begin{array}{l}\text { East of Insurgentes, Baja California Sur, Mex- } \\
\text { ico }\end{array}$ & M. gummosus & $33.1 \pm 0.13$ & - \\
\hline 20 & $\begin{array}{l}\text { Las Flores, Bahia de Los Angeles, Baja Califor- } \\
\text { nia Norte, Mexico }\end{array}$ & M. gummosus & $33.1 \pm 0.08$ & - \\
\hline 27 & El Socorro, Baja California Norte, Mexico & $\begin{array}{l}\text { Drosophila moja- } \\
\text { vensis }\end{array}$ & $33.0 \pm 0.13$ & - \\
\hline 28 & El Socorro, Baja California Norte, Mexico & D. mojavensis & $33.0 \pm 0.13$ & - \\
\hline 31 & Tucson, Ariz. & Carnegia gigantea & $33.54 \pm 0.09^{c}$ & + \\
\hline 34 & Tucson, Ariz. & C. gigantea & $32.83 \pm 0.04$ & + \\
\hline 35 & Rancho Cuñaño, Baja California Sur, Mexico & $\begin{array}{l}\text { Lophocereus schot- } \\
\text { tii }\end{array}$ & $32.9 \pm 0.16$ & + \\
\hline 38 & Mulegé, Baja California Sur, Mexico & $\begin{array}{l}\text { Pachycereus prin- } \\
\text { glei }\end{array}$ & $33.0 \pm 0.19$ & + \\
\hline
\end{tabular}

${ }^{a}$ Strains 31, 34, 35, and 38 represent $P$. amethionina var. pachycereana; the remaining strains represent $P$. amethionina var. amethionina.

${ }^{b}$ The value for strain 1 is based on six separate determinations; the value for strain 31 is based on four determinations; the values for strains 17, 20,35, and 38 are based on three determinations; and the values for strains 2,27 , and 28 are based on two determinations.

${ }^{c}$ The $\mathrm{G}+\mathrm{C}$ value of this strain differs from all other values $(\alpha=0.05)$. An earlier determination for this strain (11) was reported as $33.57 \pm 0.10$. 
TABle 4. Precursors used in determining the metabolic block in the pathway leading to the biosynthesis of methionine for all strains of Pichia amethionina

\begin{tabular}{|c|c|}
\hline Precursor added to basal medium ${ }^{a}$ & $\begin{array}{l}\text { Ability to } \\
\text { grow }\end{array}$ \\
\hline None & - \\
\hline Homoserine $\ldots \ldots \ldots \ldots \ldots \ldots$ & - \\
\hline $\mathrm{SO}_{4}^{-2} \ldots \ldots$ & - \\
\hline $\mathrm{SO}_{3}{ }^{-2}$ & - \\
\hline 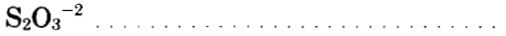 & + \\
\hline Cysteine $\ldots \ldots \ldots \ldots \ldots \ldots \ldots$ & + \\
\hline Homocysteine thiolactone . & + \\
\hline Cystathionine $\ldots \ldots \ldots \ldots$ & $t^{b}$ \\
\hline Methionine $\ldots \ldots \ldots \ldots \ldots \ldots \ldots$ & + \\
\hline
\end{tabular}

${ }^{a}$ Yeast nitrogen base without amino acids (Difco) plus $0.5 \%$ glucose and precursor $(10 \mathrm{mg} /$ liter).

${ }^{b}$ Strains 11, 17, 29, 32, and 38 exhibited latent growth, whereas strain 8 did not grow at all.

spore viabilities (e.g., strain $24 \mathbf{a} \times$ strain $36 \alpha$ yielded $20 / 32$ viable spores $=63 \%$ ). Since only four-spored asci were dissected, the spore survivals reported above represent high estimates. Nevertheless, the potential for gene flow between the two varieties is demonstrated, as is some degree of postmating breakdown, which results in partial isolation of the two gene pools. We do not know if hybrids occur in nature, but this could be easily ascertained by scoring segregants on a selective isolation medium in the field.

The two varieties of $P$. amethionina differ from each other physiologically in their ability to assimilate the sugar alcohol D-mannitol. Mannitol utilization was tested for in clones derived from spores dissected from the hybrid of the mannitol-positive strain 35 and the mannitolnegative strain 27. A single locus was implicated since five tetrads, with four viable spores each, segregated into two mannitol-positive and two mannitol-negative ascospore types. In addition, random spore analysis of 91 spores ( 39 mannitol negative; 52 mannitol positive) indicated that a single gene was responsible for the observed difference (corrected $\chi^{2}=1.58 ; \mathrm{df}=1 ; \alpha=0.05$ ).

Another interesting attribute of $P$. amethionina is the phenomenon of agglutination or clumping when opposite mating types are mixed together. The reaction is similar to the agglutination Wickerham (15) reported in Hansenula wingei. We found that the reaction is stronger for older cultures than for freshly streaked ones. Zygotes become apparent in a few (2 to 4 ) hours after mixing, and ascospores could sometimes be observed within $24 \mathrm{~h}$ (Fig. 2).

Comparative observations of the two varieties show that $P$. amethionina var. amethionina takes from 5 to 7 days to sporulate on YM agar
TABLE 5. Viability classes for spores dissected from four-spored asci of a cross (strain $27 \alpha \times$ strain 35

a) between the two varieties of $P$. amethionina

\begin{tabular}{llllcl}
\hline \multicolumn{1}{c}{ Determination } & $0^{a}$ & \multicolumn{1}{c}{1} & \multicolumn{1}{c}{2} & \multicolumn{1}{c}{3} & \multicolumn{1}{c}{4} \\
\hline Observed frequency & 1 & 18 & 15 & 9 & 7 \\
$\begin{array}{l}\text { Expected fre- } \\
\quad \text { quency }^{b}\end{array}$ & 2.8 & 11.8 & 18.7 & 13.2 & 3.5 \\
\hline
\end{tabular}

${ }^{a}$ Numbers of viable spores per ascus.

${ }^{b}$ Expectation is based on the assumption that spore viability had a binomial distribution $\mathrm{B}(\chi ; \mathrm{n}, \mathrm{p})$ with $\mathrm{n}$ $=50, \hat{\mathrm{p}}=0.515$.

after mixing opposite mating types, whereas mixes of $P$. amethionina var. pachycereana only require $24 \mathrm{~h}$ to 3 days to sporulate on the same medium. The intervarietal mixes show an intermediate time to complete the sporulation cycle. In general, we have found it more difficult to induce sporulation in $P$. amethionina var. amethionina, and we presume that its optimum sporulation conditions are somewhat different from those of the mannitol-positive variety, $P$. amethionina var. pachycereana.

Table 2 lists the frequency of isolation of the $P$. amethionina varieties from various cacti, but it does not give the number of cacti sampled. When one considers that 100 agria and 16 saguaro soft-rots were examined, it is apparent that the two varieties occupy two different niches in approximately the same frequency. In addition, saguaro, senita, and cardon belong to the subtribe Pachycereinae whereas the other cactus species are in the subtribe Stenocereinae. The subtribes are based on phylogenetic considerations, and the time of divergence of the two cactus tribes may also indicate the time of divergence for the two varieties of $P$. amethionina.

We attempted matings of haploid clones of $P$. amethionina with haploid clones of $P$. delftensis and found no conjugation. We also attempted matings with $P$. heedii (8), which has a $\mathrm{G}+\mathrm{C}$ value similar to that of $P$. amethionina, but without success. This clearly demonstrates the distinctness of these species and confirms our suspicions based on ecological considerations.

$P$. amethionina can be distinguished from other Pichia species by its unique requirement for methionine and by its cactus habitat. In addition, it differs from $P$. delftensis by its inability to assimilate ribitol and by its much higher maximum growth temperature.

\section{ACKNOWLEDGMENTS}

We thank Nancy Krauter for her help in determining the deoxyribonucleic acid base compositions and André Lachance for his help in the preparation of the illustrations and for his assistance with the Latin diagnoses. We greatly appreciate the assistance of Alexander Russell, Jr., Jean S. Russell, William R. Johnson, and Don C. Vacek with the field collections. A 
gift of Zymolyase from the Research Laboratories of Kirin Breweries Ltd., Takasaki, Japan, is gratefully acknowledged.

This research was supported, in part, by Public Health Service Grant GM-16307-07 from the National Institute of General Medical Sciences to H. J. Phaff and by a grant from the National Science Foundation to W. B. Heed and H. W. Kircher (DEB 74-19148A03).

\section{REPRINT REQUESTS}

Address reprint requests to: H. J. Phaff, Department of Food Science and Technology, University of California, Davis, CA 95616.

\section{LITERATURE CITED}

1. Bernardi, G., M. Foures, G. Piperno, and P. P. Slonimski. 1970. Mitochondrial DNAs from respiratory-sufficient and cytoplasmic respiratory-deficient mutants of yeast. J. Mol. Biol, 48:23-42.

2. Fowell, R. R. 1969. Sporulation and hybridization of yeasts, p. 363. In A. H. Rose and J. S. Harrison (ed.), The yeasts, vol. 1. Academic Press Inc., New York.

3. Heed, W. B., W. T. Starmer, M. Miranda, M. W. Miller, and H. J. Phaff. 1976. An analysis of the yeast flora associated with cactiphilic Drosophila and their host plants in the Sonoran desert and its relation to temperate and tropical associations. Ecology 57:151-160.

4. Kreger-van Rij, N. J. W. 1970. Pichia Hansen, p. 455-554. In J. Lodder (ed.), The yeasts-a taxonomic study. North-Holland Publishing Co., Amsterdam.

5. Marmur, J. 1961. A procedure for the isolation of DNA from microorganisms. J. Mol. Biol. 3:208-218.

6. Miller, M. W., H. J. Thaff, M. Miranda, W. B. Heed, and W. T. St.urmer. 1976. Torulopsis sonorensis, a new species of the genus Torulopsis. Int. J. Syst. Bacteriol. 26:88-91.
7. Phaff, H. J., M. W. Miller, M. Miranda, W. B. Heed, and W. T. Starmer. 1974. Cryptococcus cereanus, a new species of the genus Cryptococcus. Int. J. Syst. Bacteriol. 24:486-490.

8. Phaff, H. J., W. T. Starmer, M. Miranda, and M. W. Miller. 1978. Pichia heedii, a new species of yeast indigenous to necrotic cacti in the North American Sonoran Desert. Int. J. Syst. Bacteriol. 28:326-331.

9. Robichon-Szulmeister, H. de, and Y. Surdin-Kerjan. 1971. Nucleic acid and protein synthesis in yeasts: regulation of synthesis and activity, p. 335-418. In A. H. Rose and J. S. Harrison (ed.), The yeasts, vol. 2. Academic Press Inc., New York.

10. Schildkraut, C. L., J. Marmur, and P. Doty. 1962. Determination of the base composition of deoxyribonucleic acid from its buoyant density in $\mathrm{CsCl}$. J. Mol. Biol. 4:430-433.

11. Starmer, W. T., W. B. Heed, M. Miranda, M. W. Miller, and H. J. Phaff. 1976. The ecology of yeast flora associated with cactiphilic Drosophila and their host plants in the Sonoran desert. Microb. Ecol. 3:11-30.

12. Starmer, W. T., H. J. Phaff, M. Miranda, and M. W. Miller. 1978. Pichia cactophila, a new species of yeast found in decaying tissue of cacti. Int. J. Syst. Bacteriol. 28:318-325.

13. Szybalski, W. 1969. Use of cesium sulfate for equilibrium density gradient centrifugation. Methods Enzymol. 12B:330-360.

14. van der Walt, J. P. 1970. Criteria and methods used in classification, p. 34-113. In J. Lodder (ed.), The yeasts-a taxonomic study. North-Holland Publishing Co., Amsterdam.

15. Wickerham, L. J. 1956. Influence of agglutination on zygote formation in Hansenula wingei, a new species of yeast. C. R. Trav. Lab. Carlsberg Sér. Physiol. 26:423-443. 